Supplement of Nat. Hazards Earth Syst. Sci., 20, 1931-1940, 2020

https://doi.org/10.5194/nhess-20-1931-2020-supplement

(c) Author(s) 2020. This work is distributed under

the Creative Commons Attribution 4.0 License.

(c) (1)

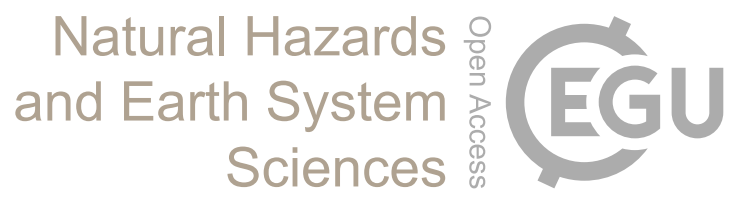

Supplement of

\title{
Brief Communication: An electrifying atmospheric river - understanding the thunderstorm event in Santa Barbara County during March 2019
}

Deanna Nash and Leila M. V. Carvalho

Correspondence to: Deanna Nash (dlnash@ucsb.edu)

The copyright of individual parts of the supplement might differ from the CC BY 4.0 License. 
(a) 4 March 201918 UTC

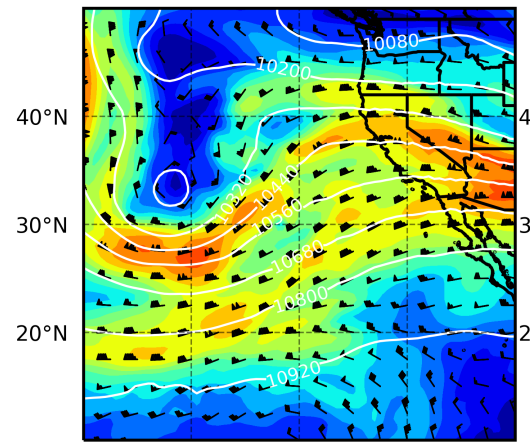

(d) 5 March 201912 UTC

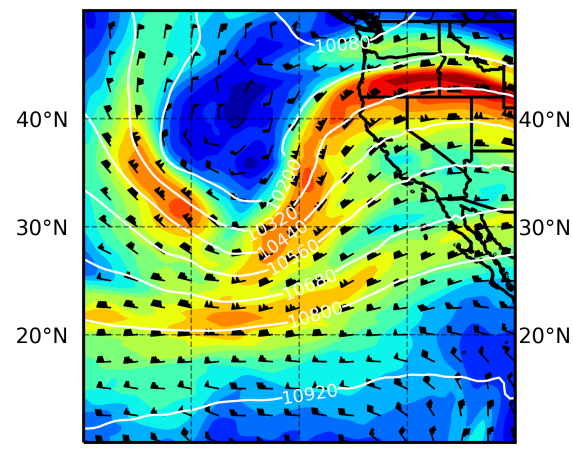

$140^{\circ} \mathrm{W} \quad 130^{\circ} \mathrm{W} \quad 120^{\circ} \mathrm{W}$

(g) 6 March 201906 UTC

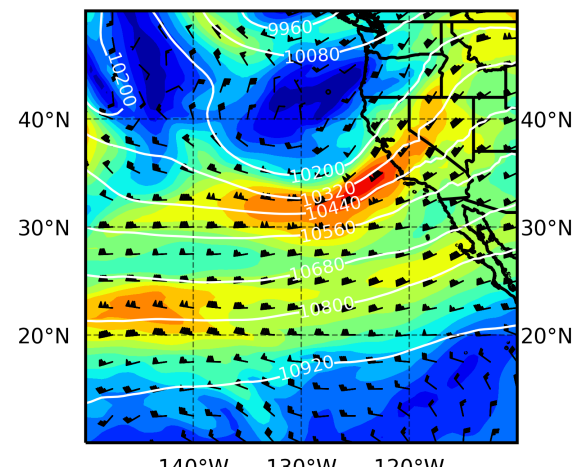

$140^{\circ} \mathrm{W} \quad 130^{\circ} \mathrm{W} \quad 120^{\circ} \mathrm{W}$ $140^{\circ} \mathrm{W} \quad 130^{\circ} \mathrm{W} \quad 120^{\circ} \mathrm{W}$ (b) 5 March 201900 UTC

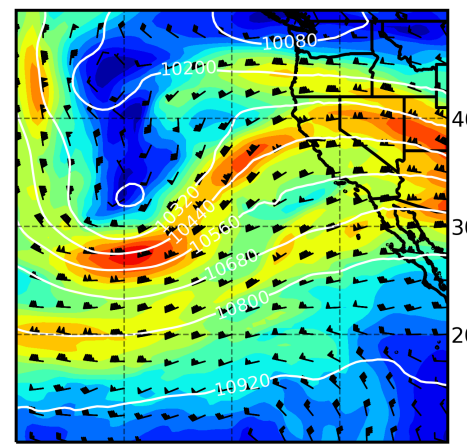

$140^{\circ} \mathrm{W} \quad 130^{\circ} \mathrm{W} \quad 120^{\circ} \mathrm{W}$

(e) 5 March 201918 UTC

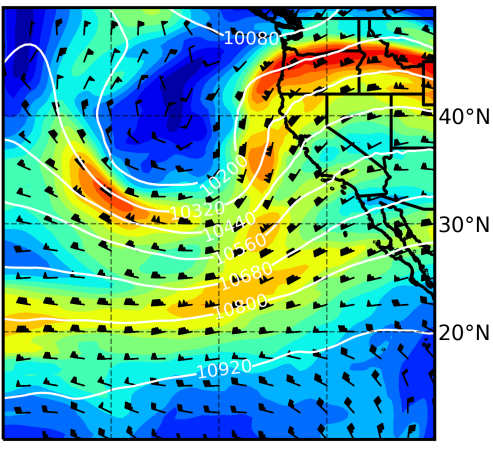

$140^{\circ} \mathrm{W} \quad 130^{\circ} \mathrm{W} \quad 120^{\circ} \mathrm{W}$

(h) 6 March 201912 UTC

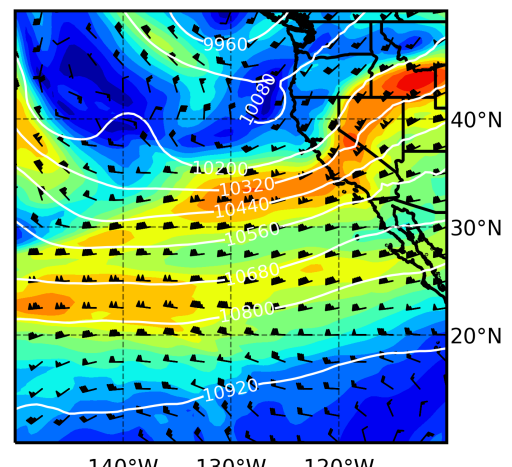

$140^{\circ} \mathrm{W} \quad 130^{\circ} \mathrm{W} \quad 120^{\circ} \mathrm{W}$ (c) 5 March 201906 UTC

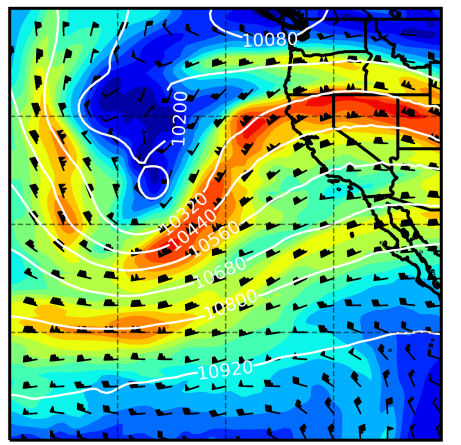

$140^{\circ} \mathrm{W} \quad 130^{\circ} \mathrm{W} \quad 120^{\circ} \mathrm{W}$

(f) 6 March 201900 UTC

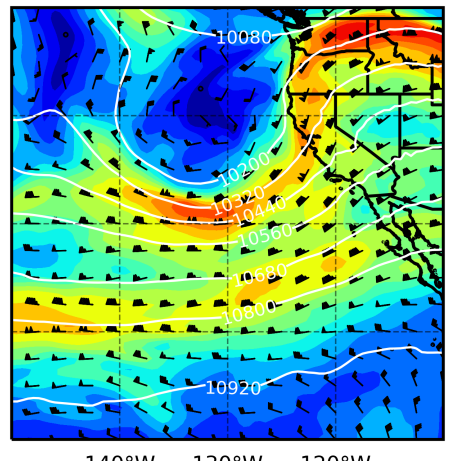

$140^{\circ} \mathrm{W} \quad 130^{\circ} \mathrm{W} \quad 120^{\circ} \mathrm{W}$

(i) 6 March 201918 UTC

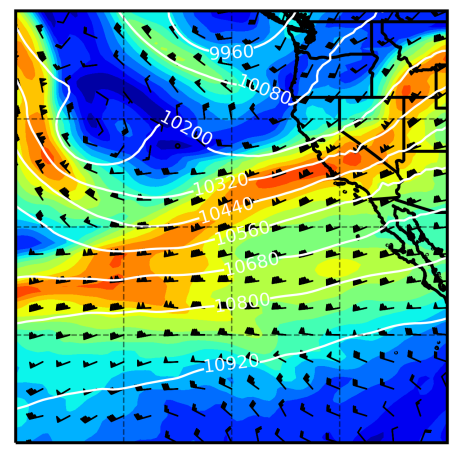

$140^{\circ} \mathrm{W} \quad 130^{\circ} \mathrm{W} \quad 120^{\circ} \mathrm{W}$
70

60 50

Figure S1. CFSv2 $250 \mathrm{hPa}$ winds (barbs, knots), $250 \mathrm{hPa}$ wind magnitude (shaded; $\mathrm{m} \mathrm{s}^{-1}$ ) and 250 hPa geopotential height (white contours; m) at 6-hourly timesteps between 4 March 201918 UTC and 6 March 201918 UTC. 

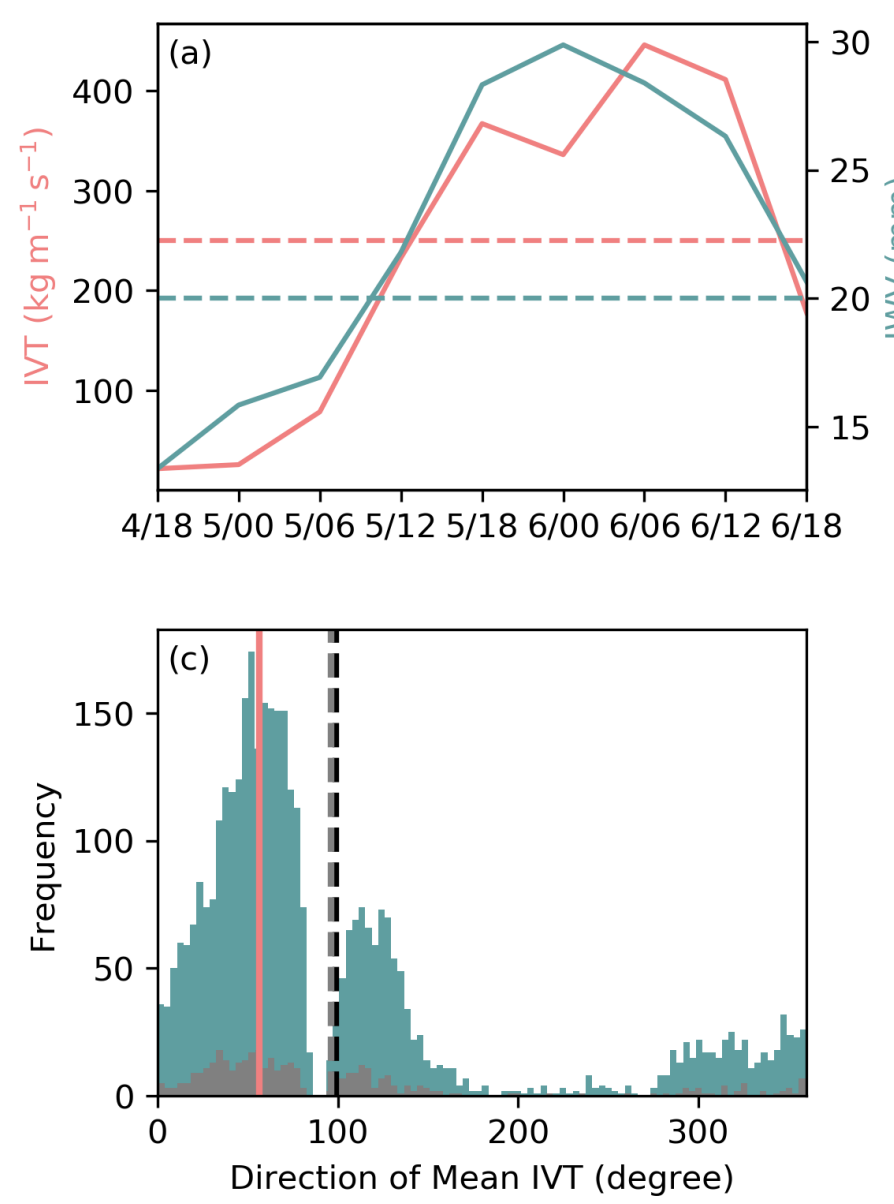
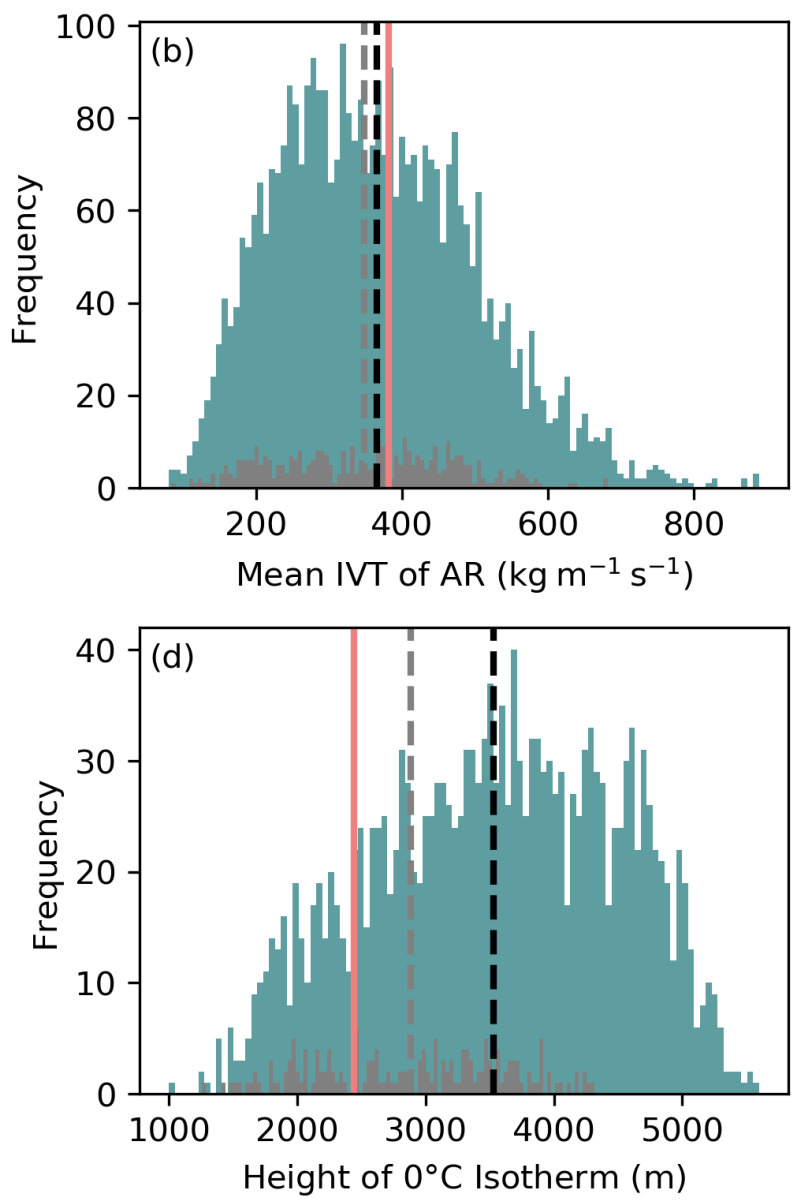

Figure S2. (a) CFSv2 IVT (red line; $\mathrm{kg} \mathrm{m}^{-1} \mathrm{~s}^{-1}$ ) and IWV (blue line; $\mathrm{mm}$ ) at the grid cell closest to Santa Barbara $\left(34.5^{\circ} \mathrm{N}, 119.5^{\circ} \mathrm{W}\right)$ at each 6-hour time step between 4 March 201918 UTC and 6 March 201918 UTC. The minimum thresholds for the location to be considered part of an AR event are indicated by the dotted lines. (b) Mean IVT of the AR objects that made landfall in Santa Barbara in all the months (blue lines) and only March (grey lines) between January 1980 and May 2019 based on the AR Catalog from Guan and Waliser (2015). The mean IVT for the AR Event on March 5 is shown by the red solid line. The means of the distributions are shown in the dotted line. (c) Same as (b) but for direction of mean IVT propagation (azimuth is $0^{\circ}$ if IVT is directed to the north). (d) Same as (b) but for the height of the $0^{\circ} \mathrm{C}$ Isotherm (m) interpolated from MERRA2 temperature and geopotential height. 
(a) 4 March 201918 UTC

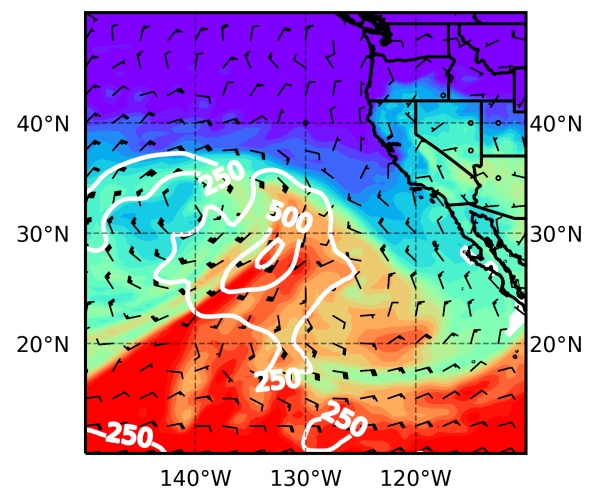

(d) 5 March 201912 UTC

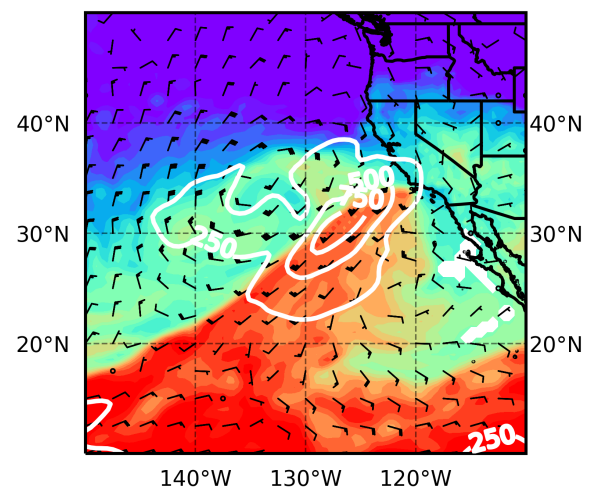

(g) 6 March 201906 UTC

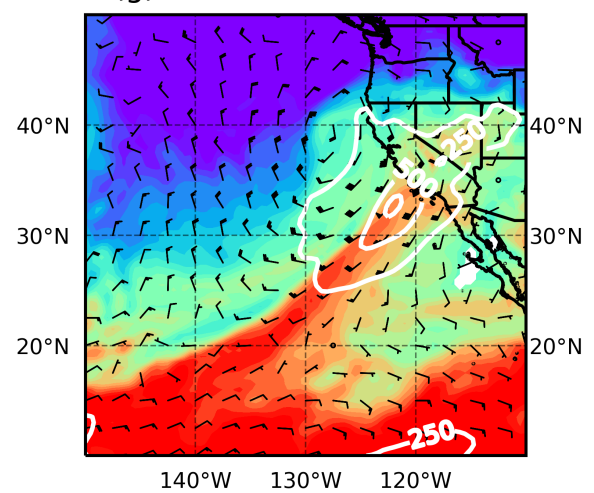

(b) 5 March 201900 UTC

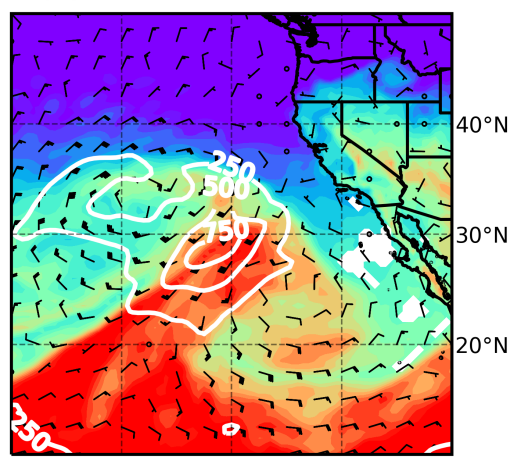

$140^{\circ} \mathrm{W} \quad 130^{\circ} \mathrm{W} \quad 120^{\circ} \mathrm{W}$

(e) 5 March 201918 UTC

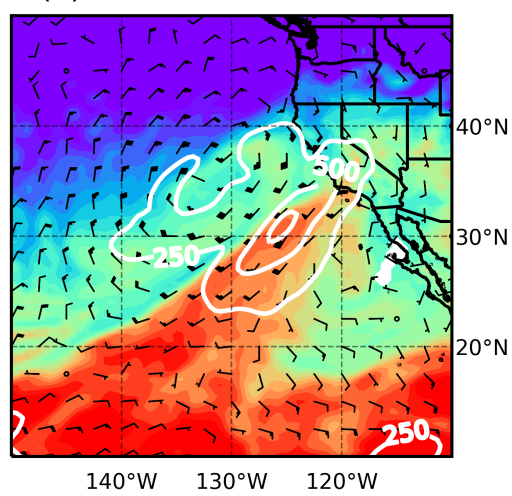

(h) 6 March 201912 UTC

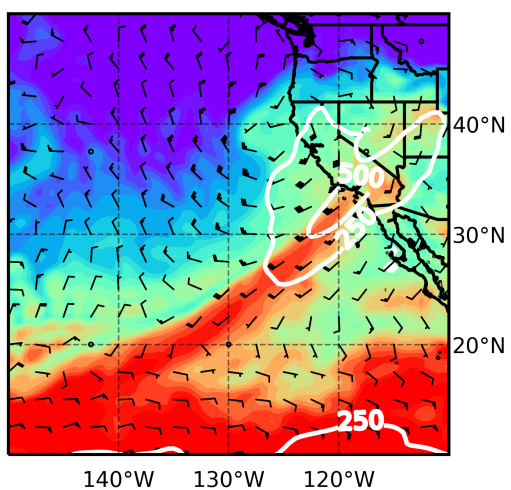

(c) 5 March 201906 UTC

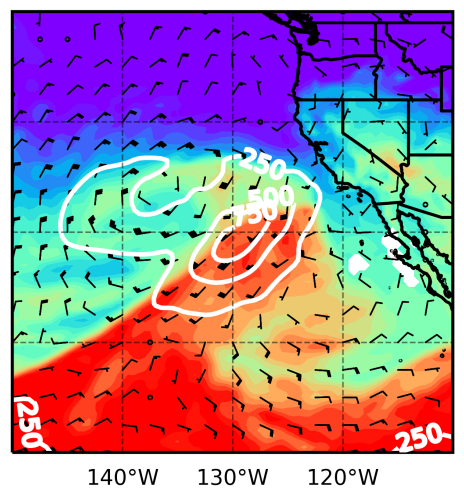

$140^{\circ} \mathrm{W} \quad 130^{\circ} \mathrm{W} \quad 120^{\circ} \mathrm{W}$

(f) 6 March 201900 UTC

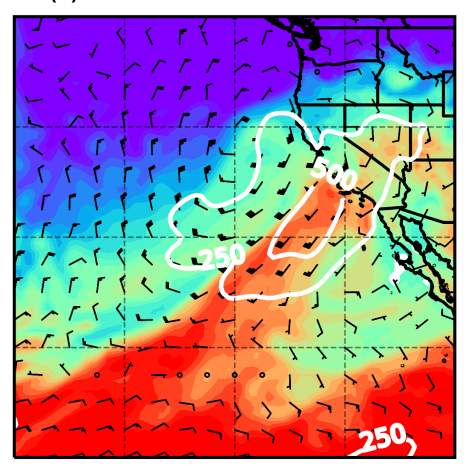

$140^{\circ} \mathrm{W} \quad 130^{\circ} \mathrm{W} \quad 120^{\circ} \mathrm{W}$ (i) 6 March 201918 UTC

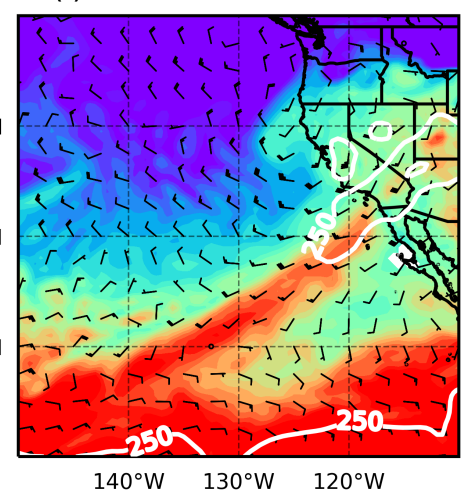

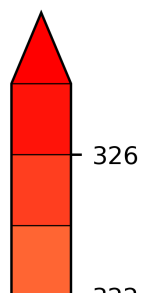

Figure S3. Figure S3. CFSv2 $850 \mathrm{hPa}$ Equivalent Potential Temperature (shaded; K), $850 \mathrm{hPa}$ winds (barbs; knots), and IVT greater than $250 \mathrm{~kg} \mathrm{~m}^{-1} \mathrm{~s}^{-1}$ (white contours; every $250 \mathrm{~kg} \mathrm{~m}^{-1} \mathrm{~s}^{-1}$ ) for each 6-hour time step between 4 March 201918 UTC and 6 March 201918 UTC. 
(a) 4 March 201918 UTC

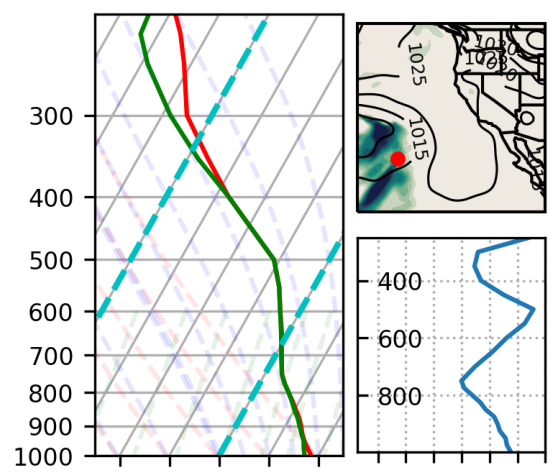

(d) 5 March 201912 UTC

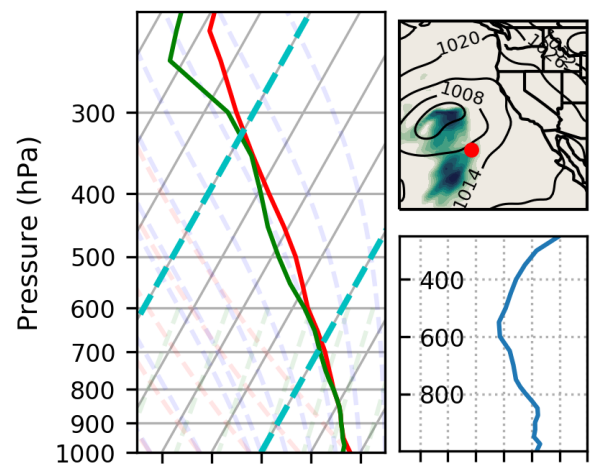

(g) 6 March 201906 UTC
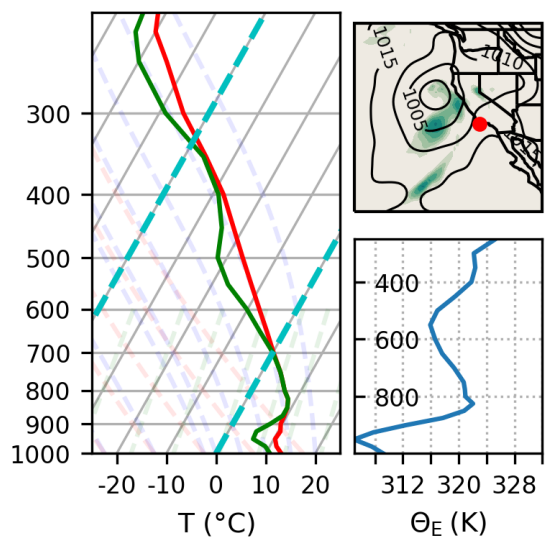

(b) 5 March 201900 UTC
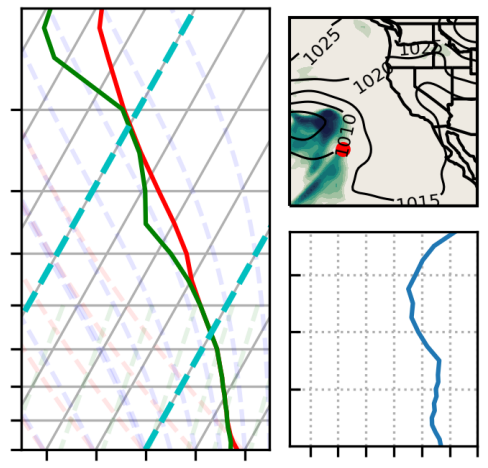

(e) 5 March 201918 UTC
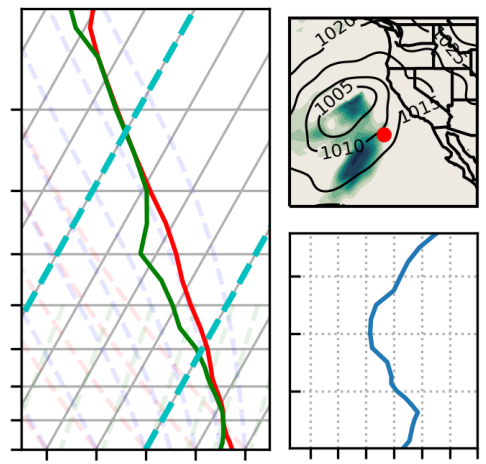

(h) 6 March 201912 UTC
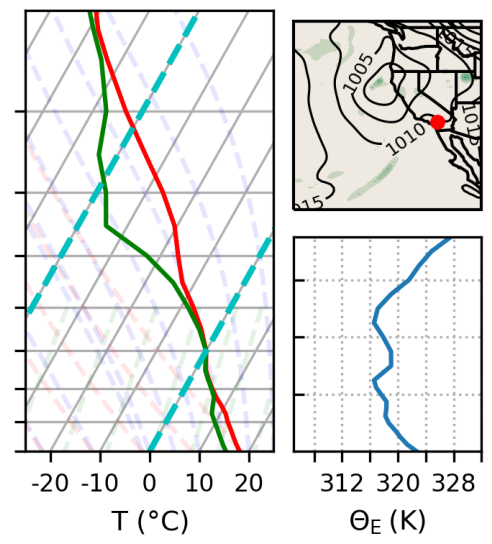

600

CAPE $\left(\mathrm{kg}^{-1}\right)$

400 (c) 5 March 201906 UTC

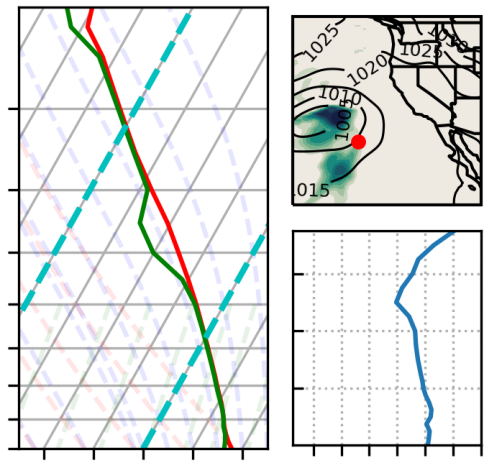

(f) 6 March 201900 UTC

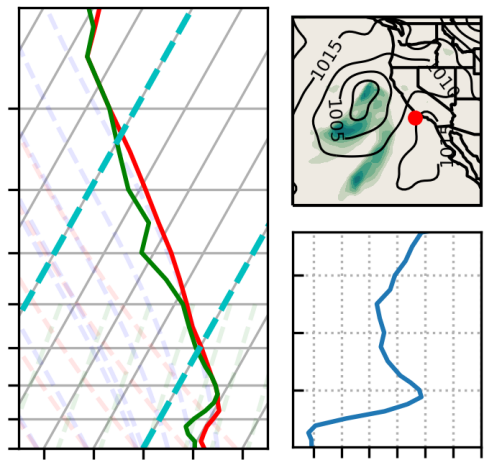

(i) 6 March 201918 UTC
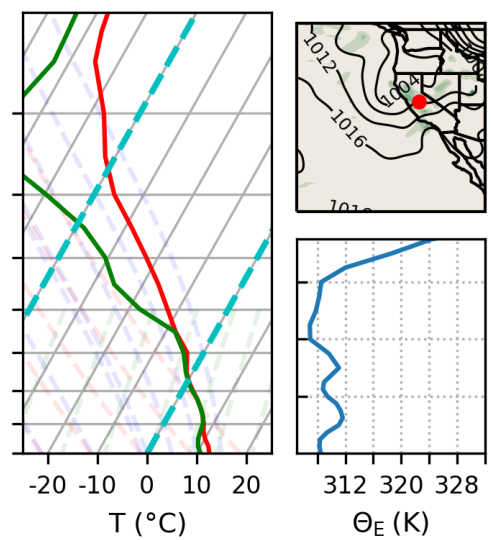

312320328

$\Theta_{\mathrm{E}}(\mathrm{K})$

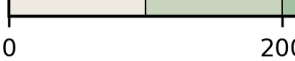

800

1000

Figure S4. (left panel) Skew $(\mathrm{t})$ - $\log (\mathrm{p})$ vertical profile of CFSv2 temperature (red line) and dew point (green line) at the grid cell with the highest flash density (per 6 hours); (right top panel) CFSv2 CAPE (shaded, $\mathrm{J} \mathrm{kg}^{-1}$ ) and MSLP (black dashed contours; hPa) with the location of the highest flash density indicated by the red dot; (right bottom panel) CFSv2 Equivalent Potential Temperature (blue line; K) at the grid cell with the highest flash density for each 6-hour time step between (a) 4 March 201918 UTC and (i) 6 March 201918 UTC. 


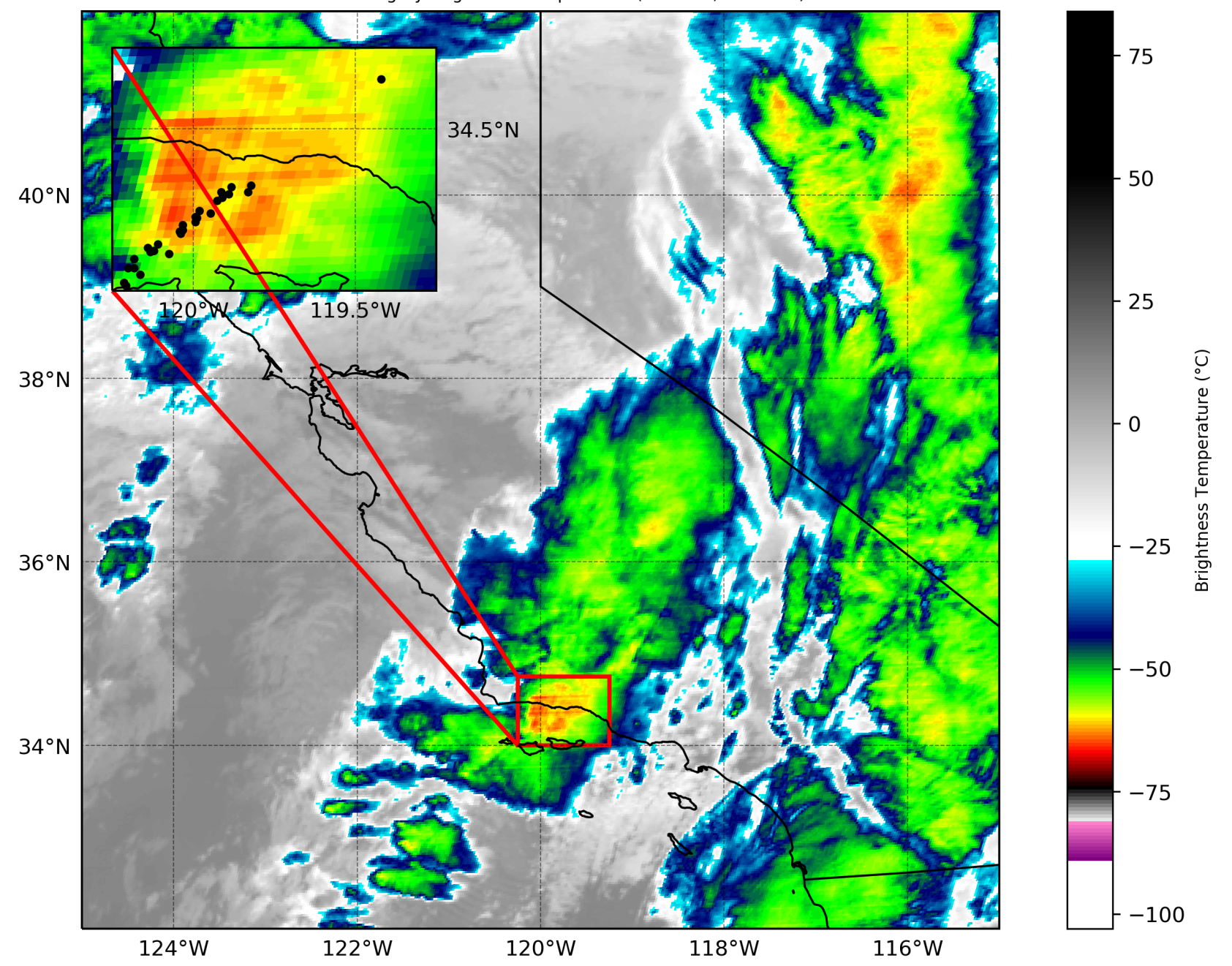

Figure S5. Infrared brightness temperatures (shaded, ${ }^{\circ} \mathrm{C}$ ) derived from band 13 of the GOES17 ABI L2 Cloud and Moisture Imagery Brightness Temperature at 6 March 2019 4:24 UTC. Detailed infrared brightness temperatures around Santa Barbara (outlined in red) are shown in the top left area of the map. Locations of NOAA NEXRAD L3 Hail Signatures (black points) identified between 4:15 UTC and 4:45 UTC on 6 March 2019 are shown on the inset map. 


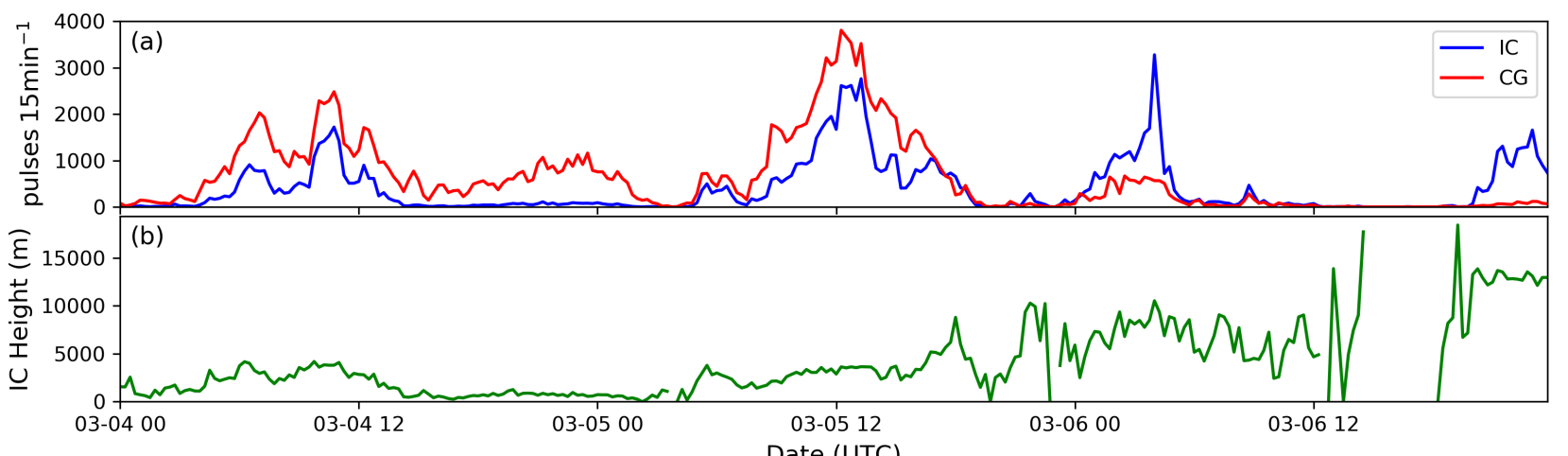

(c) 4 March 2019

(d) 5 March 2019

(e) 6 March 2019

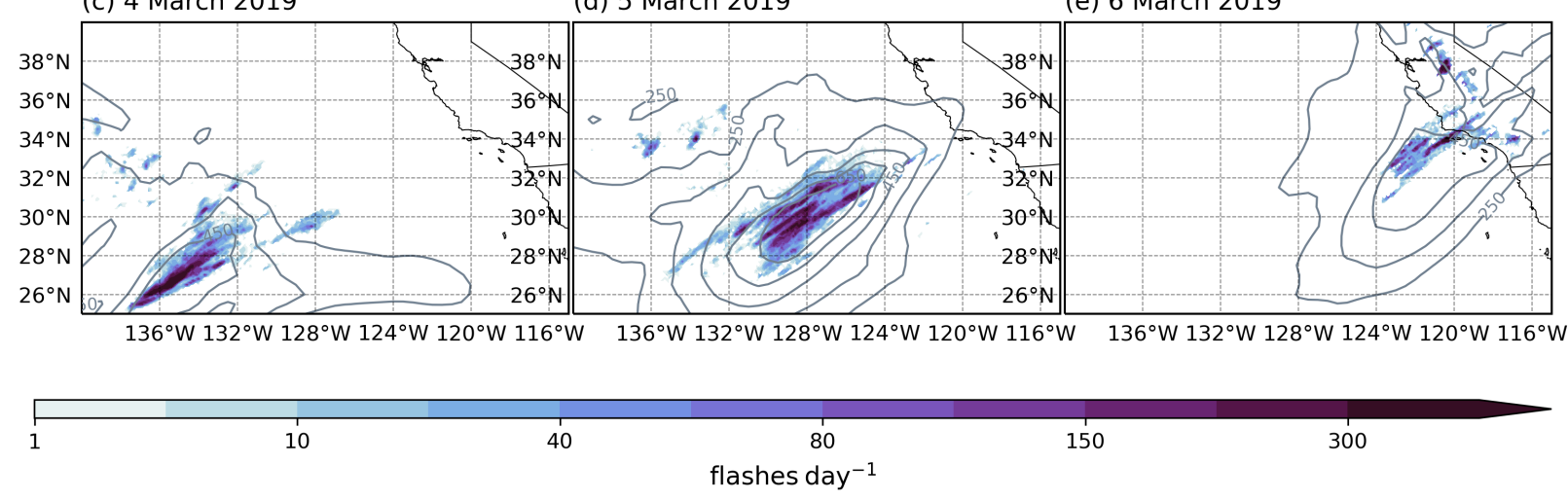

Figure S6. (a) ENGLN number of flashes per 15 minutes between 4 March 20190 UTC and 7 March 0 UTC for in-cloud (IC) flashes (blue line) and cloud-to-ground (CG) flashes (red line). (b) ENGLN average IC lightning flash height (green line; m) between 4 March 20190 UTC and 7 March 0 UTC. (c) ENGLN lightning flash count (shaded, flashes day ${ }^{-1}$ ) interpolated to $0.1^{\circ}$ and IVT greater than $250 \mathrm{~kg} \mathrm{~m}^{-1} \mathrm{~s}^{-1}$ (grey contours; every $100 \mathrm{~kg} \mathrm{~m}^{-1} \mathrm{~s}^{-1}$ ) for the 24-hour period of 4 March 2019. (d) Same as (c), but for the 24-hour period of $5 \mathrm{March} 2019$. (e) Same as (c), but for the 24-hour period of 6 March 2019. 
(a) 4 March 201918 UTC
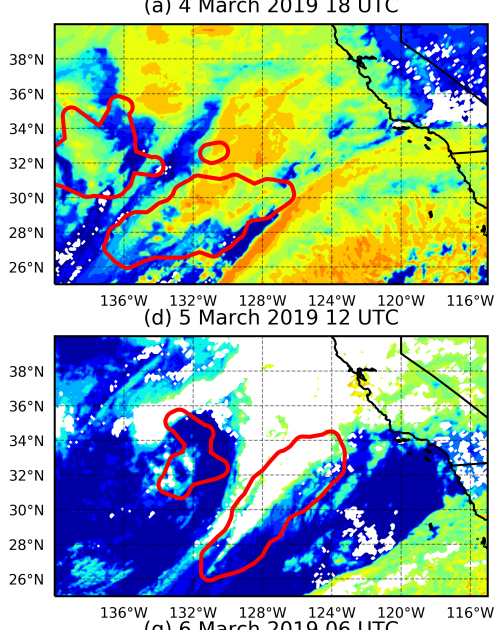

\begin{tabular}{l} 
(g) 6 March $2019^{124^{\circ}} 06$ UTC $^{120} \mathrm{~W}$ \\
\hline
\end{tabular}

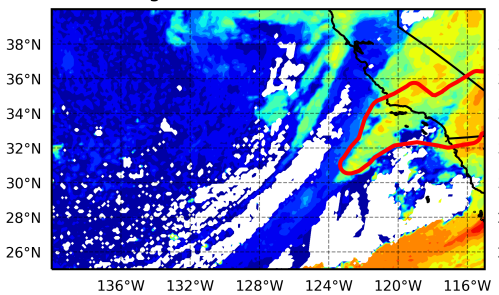

(b) 5 March 201900 UTC

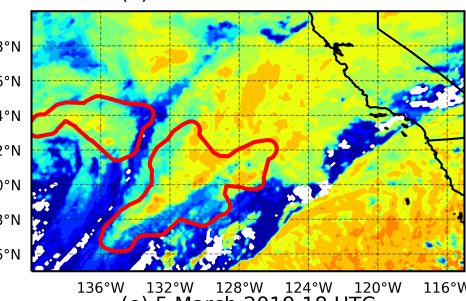

$136^{\circ} \mathrm{W} 1132^{\circ} \mathrm{W} 128^{\circ} \mathrm{W} 124^{\circ} \mathrm{W}$
(e) 5 March $2019^{120} 18$ UTC

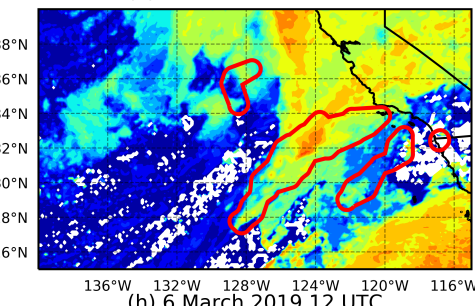

(h) 6 March 201912 UTC
$122^{\circ} \mathrm{W}$ U $128^{\circ} \mathrm{W}$

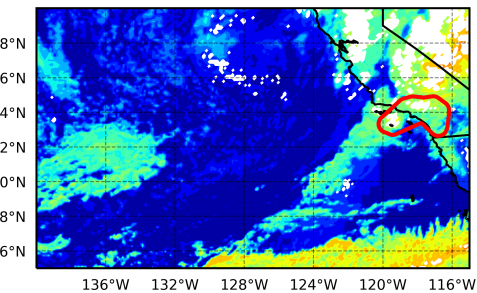

(c) 5 March 201906 UTC
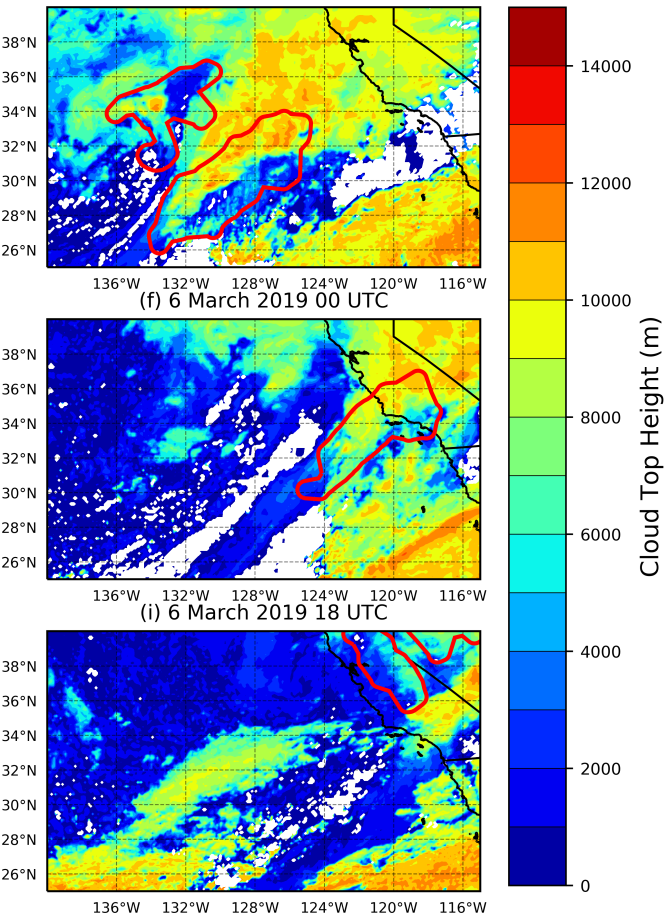

Figure S7. GOES ABI L2 ACHC cloud top height (shaded; m) and the location of the majority of lightning flash points (red polygon) at each 6-hour time step between 4 March 201918 UTC and 6 March 201918 UTC. 
(a) 4 March 201918 UTC

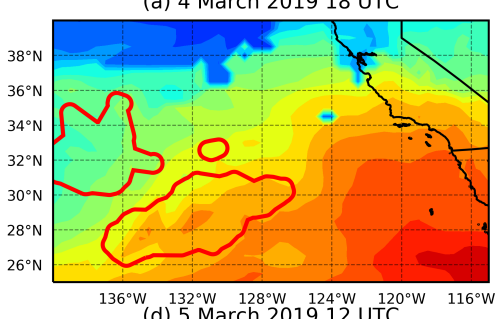

$136^{\circ} \mathrm{W}$
(d) 5 March $2012^{\circ} 122^{\circ} \mathrm{W}$ UTC
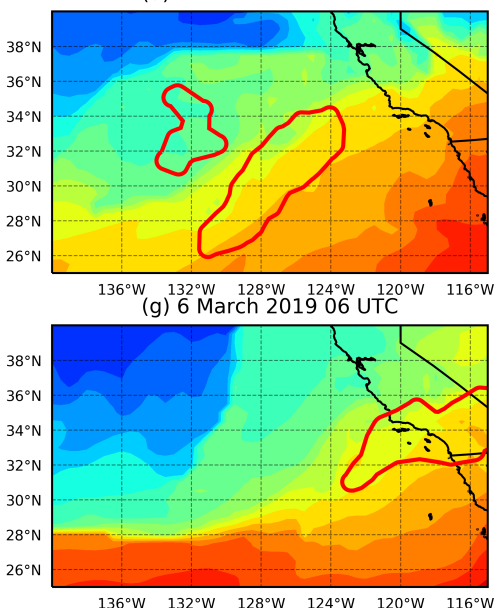

(b) 5 March 201900 UTC
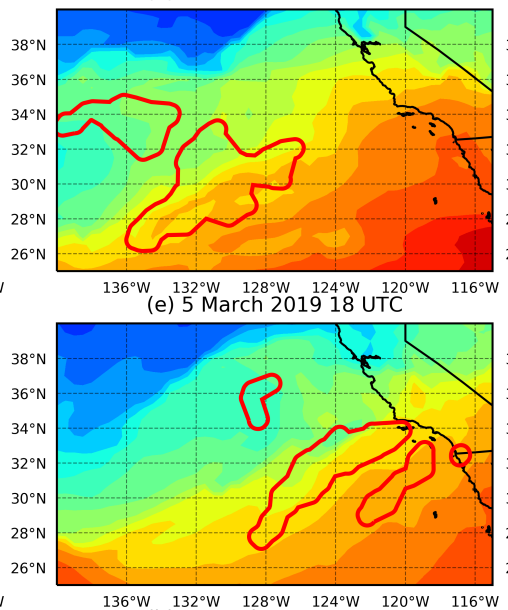

$136^{\circ} \mathrm{W} 132^{\circ} \mathrm{W} 128^{\circ} \mathrm{W} 124^{\circ} \mathrm{W}$
(h) 6 March 201912 UTC

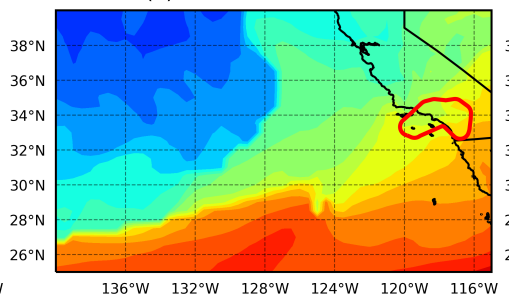

(c) 5 March 201906 UTC
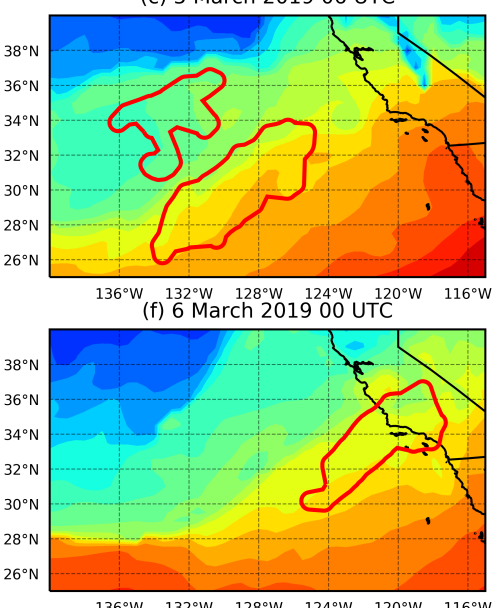

$6^{\circ} \mathrm{W} 132^{\circ} \mathrm{W} 128^{\circ} \mathrm{W} 124^{\circ} \mathrm{W}$
(i) 6 March 201918 UTC

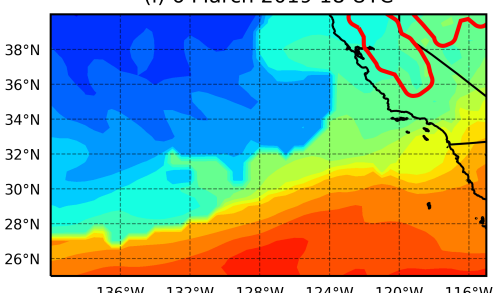

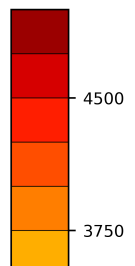

$3000 \overparen{\varepsilon}$

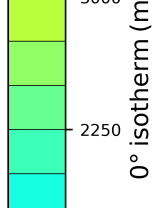

1500

750

Figure S8. CFSv2 height of $0^{\circ}$ isotherm (shaded; $\mathrm{m}$ ) and the location of the majority of lightning flash points (red polygon) at each 6-hour time step between 4 March 201918 UTC and 6 March 201918 UTC. 